\title{
Psychological Capital Affects Employee Performance: A Case at Can Tho City Radio and Television Station
}

\author{
Nguyen Lang Van Thanh ${ }^{1}$, Nguyen Quoc Nghi ${ }^{2}$ \\ ${ }^{1}$ FPT Executive MBA Program, FPT University, ${ }^{2}$ Can Tho University, Vietnam \\ Corresponding Author: Nguyen Quoc Nghi
}

DOI: https://doi.org/10.52403/ijrr.20220183

\begin{abstract}
The objective of the study is to define the influence of psychological capital on the work results of employees working at Radio and Television (TV) Station, Can Tho City. By applying quantitative analyses with the data collected from 148 employees, the research result shows that self-efficacy, optimism, hope, and resilience positively impact employees' performance. In particular, hope is the factor that has the most influence level on the performance of the Can Tho Radio and TV Station's employees.
\end{abstract}

Keywords: psychological capital, job performance, employee, Can Tho City Radio and Television Station.

\section{PROBLEM STATEMENT}

Human resources play a crucial role in the existence and development of an organization. Many companies attach great importance to human resources and management strategy. An appropriate human resource management method determines the existence and growth of a company (Luthans et al., 2007). Among the elements that create organizational competitiveness, the human advantage is considered fundamental (Luthans, 2002). People are said to be the most decisive, sustainable, and unreplaceable resource in any organization. Therefore, the issues related to personnel, especially psychological capital, a small branch of positive behavior in organizations, have always attracted the attention of researchers (Avey et al., 2010).

In the context of world economic integration, opportunities are opening up for all organizations, especially the television industry. For sustainable development, broadcaster companies have to attract human resources with specialized knowledge and work skills. Radio and TV Station of Can Tho City operate in the field of journalism, serving the demands of cultural and spiritual enjoyment in the entire city. Over the past time, the Board of Directors of Can Tho Radio and TV Station has focused on and developed its human resource, always creating favorable conditions for employees to promote their capacity and knowledge. However, evaluating and managing employees' psychological capital process has not been appropriately considered. This has more or less affected the control of employee performance. Therefore, the question for managers is how to master the issue of psychological capital to build appropriate action programs and improve employees' work results. The study "Psychological capital affects employee performance: a case at Can Tho City Radio and Television Station" is necessary to carry out. 


\section{THEORETICAL FRAMEWORK AND RESEARCH MODEL 2.1 Theoretical framework}

Psychological capital is considered as "a state of positive psychological development of an individual, which is expressed by: (1) Confident enough to strive and overcome challenges to succeed, (2) Be optimistic in the present and future job, (3) Persistently pursue goals and make the necessary efforts to devise specific strategies to achieve goals and succeed, and (4) Facing with obstacles and problems, persistently find out solutions to success (Luthans et al., 2007). To identify the factors that constitute psychological capital (Psycap),

Luthans et al. (2002) argued that these factors must be based on theory and practical studies, measurable, and have the status. Besides, researches by Luthans et al. (2002, 2007) have shown four factors of positive psychology that meet the above criteria: self-efficacy, hope, optimism, and resilience. Stajkovic (2006) also developed the above four factors for the "core confidence" motivation model, thereby further confirming the reality of the four factors proposed by Luthans.

Job performance is a term often used in personnel psychology to refer to work results in the workplace. Job performance is a part of human resources management. An employee's job performance indicates whether that employee does the job well or not in the workplace. Job performance is the achievement of an individual in the workplace, which is related to resultoriented planning and organizational policies (Avey et al., 2010). As presented by Rotundo and Sackett (2002), job outcomes include quantity, quality, working skills, and professional knowledge of employees. According to Karunanithy and
Ponnampalam (2013), job performance is measured by the criteria of time principle, relationship with customers, relationship with colleagues, feedback from superiors, and self-efficacy.

\subsection{Research model}

According to Stajkovic and Luthans (1998), self-confidence has a strong relationship with work performance. Légal and Meyer (2009) have suggested that there is a correlation between confidence and job performance. Researches also show that managers can improve employee productivity through their optimism. People with a high-hope trait will work hard towards goals and have the ability to overcome obstacles to achieve success (Avey et al., 2010). Resilience is the trait of a person who does not give up, always looks for other opportunities to be successful (Bonanno, 2004). In studies in 2012, 2014, Nghi has proven that confidence, optimism, hope, and resilience have positive impacts on employee performance. Psychological capital has a positive influence and plays an essential role in employees' performance (Tran Thanh Phong and Phan Duc Dung, 2020; Tan and Thanh, 2020).

Based on the literature review, the research hypotheses are posed as follows. H1: Self-efficacy has a positive effect on employees' performance of Can Tho City Radio and TV Station. H2: Optimism positively affects employee performance at Can Tho City Radio and TV Station. H3: Hope has a positive influence on the performance of the staff at Can Tho City Radio and TV Station. H4: Resilience beneficially impacts employees' job performance at Can Tho City Radio and TV Station.

The research model is as below: 
Nguyen Lang Van Thanh et.al. Psychological capital affects employee performance: a case at Can Tho City Radio and Television Station.

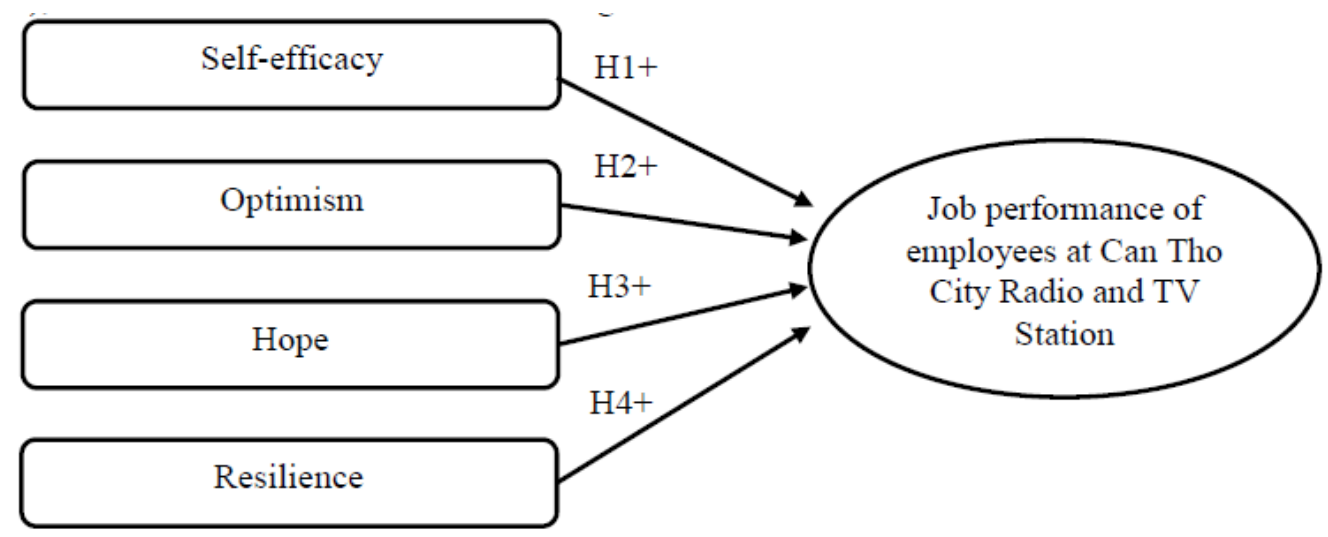

Figure 1: Proposed research model

According to the proposed research model, the dependent variable in the research model is the job performance of the staff at Can Tho Radio and TV Station. The independent variables include confidence, optimism, hope, and resilience.

Table 1: Interpretation of observed variables in the research model

\begin{tabular}{|c|c|c|}
\hline Factor & Observed variable & Reference resources \\
\hline $\begin{array}{l}\text { Self-efficacy } \\
\quad(\mathrm{SE})\end{array}$ & $\begin{array}{l}\text { SE1: I am confident in analyzing and finding solutions to } \\
\text { problems at work; } \\
\text { SE2: I am confident in presenting my work to the leader; } \\
\text { SE3: I am confident in interacting with colleagues inside and } \\
\text { outside the company; } \\
\text { SE4: I am confident in discussing work with colleagues. }\end{array}$ & $\begin{array}{l}\text { Hmieleski and Carr (2007), Özkalp (2009), Nghi } \\
\text { (2014), Phong and Dung (2020), Tan and Thanh } \\
\text { (2020) }\end{array}$ \\
\hline Optimism (OP) & $\begin{array}{l}\text { OP1: When I have difficulties at work, I believe that good } \\
\text { results will come to me; } \\
\text { OP2: I always expect everything to go my way; } \\
\text { OP3: In general, I always believe that everything at work is } \\
\text { good for me. }\end{array}$ & $\begin{array}{l}\text { Schneider (2001), Lopez and Snyder (2003), Nghi } \\
\text { (2014), Tan and Thanh (2020) }\end{array}$ \\
\hline Hope (HO) & $\begin{array}{l}\text { HO1: I actively pursue the goals of my current job; } \\
\text { HO2: I have many ways to pursue the goals at work; } \\
\text { HO3: I have many ways to solve problems at work. }\end{array}$ & $\begin{array}{l}\text { Snyder et al. (2002), Nghi (2014), Phong and Dung } \\
\text { (2020), Tan and Thanh (2020) }\end{array}$ \\
\hline Resilience (RE) & $\begin{array}{l}\text { RE1: I easily recover from problems at work; } \\
\text { RE2: I get along well with my colleagues; } \\
\text { RE3: It's easy to regain my composure when I get angry at } \\
\text { work. }\end{array}$ & $\begin{array}{l}\text { Lopez and Snyder (2003), Luthans et al. (2007), Phong } \\
\text { and Dung (2020) }\end{array}$ \\
\hline $\begin{array}{l}\text { Job performance } \\
\qquad(\mathrm{JP})\end{array}$ & $\begin{array}{l}\text { JP1: I believe that I am an effective employee; } \\
\text { JP2: I am satisfied with the job quality; } \\
\text { JP3: My leader believes that I am an effective employee; } \\
\text { JP4: My colleagues consider me an effective employee. }\end{array}$ & $\begin{array}{l}\text { Luthans et al. (2007), Nghi (2014), Phong and Dung } \\
\text { (2020), Tan and Thanh (2020) }\end{array}$ \\
\hline
\end{tabular}

\section{RESEARCH METHODOLOGY}

The hypothesis testing is carried out in three steps. Step 1: Use Cronbach's Alpha coefficient to test the correlation between observed variables. Step 2: Use exploratory factor analysis (EFA) to evaluate the convergent and discriminant validity of each variable. Step 3: Use multivariable linear regression to test the research hypotheses.

According to Tho (2011), the sample size depends on many factors such as the data analysis method and the reliability. Hair et al. (1998) have suggested that, in EFA, the sample size should be at least 50, preferably 100. The observation/ measurement ratio is $5 / 1$, meaning that one measurement variable needs at least five observations. The proposed research model has 17 observed variables, so the required minimum sample size should be 17 × $5=$ 85. The fact shows that the study has surveyed 148 employees who are currently working at Can Tho City Radio and TV Station. Thus, the collected data ensures reliability requirements.

\section{RESEARCH RESULTS AND DISCUSSION}

To test the research model about the influence of psychological capital on job performance of the staff at Can Tho Radio 
and TV Station, the study uses SPSS software to support analyses, the test results are presented below.

\subsection{Test the reliability of scales}

The study uses Cronbach's alpha coefficient to test the reliability of the scales. The test results in table 2 show that all scales have high Cronbach's alpha values (>0.7). The corrected item-total correlation of variables is greater than 0.3 , so no variable is excluded from the research model (Nunnally, 1978; Peterson, 1994; Slater, 1995). Therefore, all observations are satisfactory and can be included in the exploratory factor analysis.

\begin{tabular}{|l|l|l|l|}
\hline \multicolumn{1}{|l|}{ Table 2: Reliability test result } \\
\hline Factor & $\begin{array}{l}\text { Number of } \\
\text { observed } \\
\text { variables }\end{array}$ & $\begin{array}{l}\text { Min } \\
\text { corrected } \\
\text { item-total } \\
\text { correlation }\end{array}$ & $\begin{array}{l}\text { Cronbach's } \\
\text { Alpha }\end{array}$ \\
\hline Self-efficacy & 4 & 0.438 & 0.707 \\
\hline Optimism & 3 & 0.592 & 0.830 \\
\hline Hope & 3 & 0.669 & 0.851 \\
\hline Resilience & 3 & 0.514 & 0.747 \\
\hline Job performance & 4 & 0.460 & 0.872 \\
\hline
\end{tabular}

\subsection{Exploratory factor analysis (EFA)}

The proposed research model requires the exploratory factor analysis to perform twice with independent factors and the dependent factor. The EFA for independent scales achieved the following results: (1) Factor loading value of scales > 0.5 . (2) Suitability test of the model $(0.5<$ $\mathrm{KMO}=0.745<1.0$ ). (3) Bartlett's test on correlation of observed variables (Sig. = $0.00<0.05)$. (4) Total variance explained $=$ $68.16 \%>50 \%$. Hence, the observed variables achieve discriminant and convergent validity (Hair et al., 1998). Thereby, 4 independent factors (selfefficacy, optimism, hope, and resilience) are created from 13 observed variables. There is no disturbance among variables, so the factors' names remain the same. Similarly, the EFA results of the Job performance scale achieves the following values: (1) Factor loading $>0.5$; (2) Testing the model's suitability $(0.5<\mathrm{KMO}=0.806<$ 1.0). (3) Bartlett's test on correlation of observed variables (Sig. $=0.00<0.05$ ). (4) Total variance explained $=72.62 \%>50 \%$. The observed variables achieve discriminant and convergent validity (Hair et al., 1998). Therefore, this factor has no variable disturbance, so its name remains the same as in the proposed research model.

Table 3: Exploratory factor analysis test result

\begin{tabular}{|c|l|l|}
\hline Sign & Observed variables & Factor \\
\hline SE & 4 variables: SE1, S2, SE3, SE4 & Confidence \\
\hline OP & 3 variables: OP1, OP2, OP3, OP4 & Optimism \\
\hline HO & 3 variables: HO1, HO2, HO3, HO4 & Hope \\
\hline RE & 3 variables: RE1, RE2, RE3 & Resilience \\
\hline JP & 4 variables: JP1, JP2, JP3, JP4 & Job performance \\
\hline \multicolumn{2}{|c|}{ Source: Survey data, 2021 }
\end{tabular}

\subsection{Multivariate linear regression}

Before testing the model, the study implements the exploratory testing on the regression model through the VIF and Durbin-Watson tests. The results show that the Durbin-Watson value of the model is 1.468 , which means the model does not have autocorrelation (Nam, 2008). Besides, the variation inflation factor (VIF) of independent variables is much smaller than 4 , so there is no multicollinearity (Trong and Ngoc, 2008).

Table 4: Multivariate linear regression test result

\begin{tabular}{|c|c|c|c|c|}
\hline Factor & Standardized coefficient & Significance level (Sig.) & Variance inflation factor (VIF) & Hypothesis \\
\hline Self-efficacy & 0.132 & 0.022 & 1.095 & H1: accepted \\
\hline Optimism & 0.289 & 0.000 & 1.143 & H2: accepted \\
\hline Hope & 0.319 & 0.000 & 1.196 & H3: accepted \\
\hline Resilience & 0.378 & 0.000 & 1.238 & H4: accepted \\
\hline Adjusted $\mathrm{R}^{2}$ & & & & 0.575 \\
\hline Durbin-Watson stat & & & & 1.468 \\
\hline Sig.F & & & & 0.000 \\
\hline
\end{tabular}

The analysis in table 4 shows that the significance level of the model (Sig.F $=$ 0.00 ) is much smaller than $\alpha=5 \%$, so the regression model is significant. This means there is at least one independent variable that affects employees' performance. The 
adjusted $\mathrm{R} 2=57.5 \%$ meaning that $57.5 \%$ of the variation of the job performance factor is explained by independent factors included in the model.

Based on the results in table 4, all four factors in the model are statistically significant at the 5\% level and positively correlated with job performance. In other words, self-efficacy, optimism, hope, and resilience positively affect the performance of Can Tho Radio and TV Station's employees. This implies that high psychological capital leads to an increase in employees' performance. In which, resilience puts the most impacts on the job results. These findings are similar to researches by Schneider (2001), Lopez and Snyder (2003), Hmieleski and Carr (2007), Özkalp (2009), Nghi (2014), Phong and Dung (2020), Tan and Thanh (2020).

\section{CONCLUSION}

Overall, the study has achieved the set goal, which is to prove the influence of psychological capital on the work results of Can Tho Radio and TV Station's staff. The factors of self-efficacy, optimism, hope, and resilience positively affect employees' job performance. In which, the factor of resilience has the highest impact level on the performance. The research results are a useful scientific basis, helping the Can Tho Radio and TV Station develop an action program to improve employees' psychological capital and job performance.

\section{Acknowledgement: None}

\section{Conflict of Interest: None}

\section{Source of Funding: None}

\section{REFERENCES}

1. Avey, J. B., Luthans, F., \& Youssef, C. M. (2010). The additive value of positive psychological capital in predicting work attitudes and behaviors. Journal of Management, 36(2), 430-452.

2. Bonanno, G. A. (2004). Loss, trauma, and human resilience: have we underestimated the human capacity to thrive after extremely aversive events? American psychologist, 59(1), 20-28.

3. Hair, J. F., Tatham, R. L., Anderson, R. E., \& Black, W. (1998). Multivariate Data Analysis (5th ed.). New Jersey: PrenticeHall, Inc.

4. Hmieleski, K. M., \& Carr, J. C. (2007). The relationship between entrepreneur psychological capital and well-being. Frontiers of Entrepreneurship Research, 27(5), 1-12.

5. Karunanithy, K., \& Ponnampalam, A. (2013). A study on the effect of stress on the performance of employees in Commercial Bank of Ceylon in the Eastern Province. European Journal of Business and Management, 5(27), 87-95.

6. Légal, J. B., \& Meyer, T. (2009). Goal priming and self-efficacy: independent contributions to motor performance. Perceptual and motor skills, 108(2), 383391.

7. Lopez, S. J., \& Snyder, C. R. (2003). Positive psychological assessment: A handbook of models and measures (pp. xvii495). American Psychological Association.

8. Luthans, F. (2002). Positive organizational behavior: Developing and managing psychological strengths. Academy of Management Perspectives, 16(1), 57-72.

9. Luthans, F., Avolio, B. J., Avey, J. B., \& Norman, S. M. (2007). Positive psychological capital: Measurement and relationship with performance and satisfaction. Personnel Psychology, 60(3), 541-572.

10. Nam, M. V. (2008). Econometrics. Hanoi: Culture and Information Publishing House.

11. Nghi, N. Q. (2012), Psychological capital, working environment, and performance of bank employees in Can Tho City. Banking Technology Review, 72(03), 12-18.

12. Nghi, N. Q., Hien, L. T. D., \& Trinh, B. V. (2014). The influence of psychological capital and working environment on performance. Journal of Science of Finance and Accounting, 3, 59-64.

13. Nunnally, J. (1978). Psychometric Theory. New York: McGraw-Hill.

14. Özkalp, E. A. (2009). New Dimension in Organizational Behavior: A positive (positive) approach and organizational behavior issues. In Proceedings of 17 th National Management and Organization Congress (pp. 491-498). 
15. Peterson, R. (1994). A meta-analysis of Cronbach's coefficient alpha. Journal of Consumer Research, 21(2), 381-391.

16. Phong, T. T., \& Dung, P. D. (2020). Psychological capital affecting job performance - A study of some universities in the South. Journal of Science and Technology, 56(3), 138-143.

17. Rotundo, M., \& Sackett, P. R. (2002). The relative importance of task, citizenship, and counterproductive performance to global ratings of job performance: A policycapturing approach. Journal of applied psychology, 87(1), 66-80.

18. Schneider, S. L. (2001). In search of realistic optimism: Meaning, knowledge, and warm fuzziness. American psychologist, 56(3), 250-263.

19. Slater, S. (1995). Issues in Conducting Marketing Strategy Research. Journal of Strategic, 3(4), 257-270.

20. Snyder, C. R., Rand, K. L., \& Sigmon, D. R. (2002). Hope theory: A member of the positive psychology family. In C. R. Snyder \& S. J. Lopez (Eds.), Handbook of positive psychology (pp. 257-276). New York: Oxford University Press.

21. Stajkovic, A. D. (2006). Development of a core confidence-higher order construct.
Journal of Applied Psychology, 91(6), 1208-1224.

22. Stajkovic, A. D., \& Luthans, F. (1998). Social cognitive theory and self-efficacy: Goin beyond traditional motivational and behavioral approaches. Organizational Dynamics, 26(4), 62-74.

23. Tan, P. Q., \& Thanh, B. T. (2020). The influence of psychological capital on work commitment and employee performance: The case of electric-electronic enterprises in industrial zones in Ho Chi Minh City. Journal of Asian Business and Economic Studies, 29(6), 71-92.

24. Tho, N. D. (2011). Methods of scientific research in business. Hanoi: Publisher Socialist Labor.

25. Trong, H., \& Ngoc, C. N. M. (2008). Data analysis with SPSS. Hanoi: Statistical Publishing House.

How to cite this article: Nguyen Lang Van Thanh, Nguyen Quoc Nghi. Psychological capital affects employee performance: a case at Can Tho City Radio and Television Station. International Journal of Research and Review. 2022; 9(1): 722-727. DOI: https://doi.org/10. 52403/ijrr.20220183 